\title{
Pengaruh Iklan Pop-Up Bukalapak Versi Pahlawan Pada Youtube Terhadap Sikap Khalayak
}

\author{
Rivky Husein Ammarie, Sylvie Nurfebiaraning \\ Program Studi Ilmu komunikasi, Fakultas Komunikasi dan Bisnis Universitas Telkom
}

\begin{abstract}
ABSTRAK
Perkembangan media turut ambil bagian dalam penyebaran informasi khususnya dalam periklanan yang digunakan oleh perusahaan, salah satunya adalah beriklan pada situs YouTube. Salah satu perusahaan pengguna YouTube sebagai media periklanan adalah Bukalapak. Dengan menggunakan format iklan pop-up berupa video yang muncul secara tiba-tiba di layar ketika mengakses video. Penggunaan iklan pop-up pada YouTube dapat mempengaruhi khususnya sikap khalayak dalam mengakses situs YouTube. Dalam penelitian ini iklan video Bukalapak yang di jadikan iklan pop-up adalah iklan yang bertemakan pahlawan pada bulan Agustus - Oktober 2016. Berdasarkan tampilan data statistik pada YouTube, peneliti tertarik untuk mengetahui pengaruh iklan pop-up Bukalapak versi pahlawan pada YouTube terhadap sikap khalayak. Komponen sikap khalayak yang diteliti dalam penelitian ini adalah komponen kognitif, afektif, dan konatif. Penelitian ini menggunakan metode penelitian deskriptif yang bersifat kausal. Teknik sampling yang digunakan adalah insidental sampling sebanyak 100 responden melalui penyebaran kuisioner. Teknik analisis data yang digunakan ialah regresi sederhana dan analisis statistik deskriptif. Hasil penelitian ini menjelaskan persentase tanggapan terhadap iklan pop-up Bukalapak versi pahlawan pada YouTube sebesar 71,21\%, sedangkan pada sikap khalayak 67,55\%. Variabel komponen audiovisual iklan pop-up Bukalapak versi pahlawan pada YouTube memiliki pengaruh sebesar 57,5\%. Sehingga dapat dikatakan bahwa pengaruh iklan pop-up Bukalapak versi pahlawan pada YouTube memliki pengaruh yang cukup tinggi terhadap sikap khalayak.

Kata Kunci: Iklan Pop-up, Sikap Khalayak, Kognitif, Afektif, Konatif
\end{abstract}

\section{The Effect Of Bukalapak Pop-Up Ads Hero Version On Youtube Towards The Attitude Of The Audience}

\begin{abstract}
The development of the media took part in the dissemination of information in particular in advertising used by companies, one of which is advertising on YouTube. One of the company that use of YouTube as an advertising media is Bukalapak. Using the pop-up ads format in the form of a video that appeared suddenly on the screen when accessing the video. The use of pop-up ads on YouTube can affect the attitude of audience in accessing YouTube in particular. In this research a Bukalapak video ads that use as pop-up ad is the heroes themed one on August-October 2016. Based on statistical data display on YouTube, researchers interested to know the influence of pop-up ads Bukalapak version of the hero on YouTube towards the attitude of the audience. Components of the attitude of the audience that was examined in this study is a component of cognitive, affective, and conative. This research use descriptive research methods that are causal descriptve method. The sampling techniques used are incidental sampling of 100 respondents through the distribution of the questionnaire. Data analysis technique used is a regression liniear analysis and descriptive statistics. The results of this research describes the percentage of the response to the pop-up ads Bukalapak version of the hero on YouTube is 71,21\%, while on the attitudes of the audiences 67,55\%. The variable
\end{abstract}


component of the audiovisual pop-up ads Bukalapak version of the hero on YouTube have influence is 57,5\%. So it can be concluded that the influence of pop-up ads Bukalapak version of the hero on YouTube has influence high enough towards the attitude of the audience. Keywords: pop-up ads, Attitude of the audience, Cognitive, Affective, Conative

Korespondensi: Rivky Husein Ammarie. Universitas Telkom. Jl. Telekomunikasi, Jl. Terusan Buah Batu No.01, Sukapura, Dayeuhkolot, Bandung, Jawa Barat 40257 Email: rivky008@gmail.com

\section{PENDAHULUAN}

Perkembangan media teknologi yang semakin berkembang dari tahun ke tahun sangat mempengaruhi kehidupan sehari-hari dalam masyarakat terutama dalam melaksanakan aktivitas. Apalagi dalam perkembangan teknologi handphone, komputer, laptop, dan bahkan notebook. Halhal yang disebutkan diatas sangat berkaitan dengan masyarakat, karena setiap orangorang sangat bergantung pada teknologi dan menjadikan teknologi tersebut sebagai kebutuhan. Perkembangan dunia teknologi dan informasi semakin pesat dalam beberapa dekade terakhir, sehingga menjadikan internet sebagai alat komunikasi yang banyak diminati oleh masyarakat di seluruh dunia. Hal inilah yang melatar belakangi perubahan komunikasi konvensional menjadi modern dan serba digital (perkembangan dunia teknologi dalam Yasundari, 2016).

Perkembangan teknologi tersebut awalnya hanya digunakan untuk mempermudah manusia dalam melakukan berbagai aktivitas. Dalam aktivitas sehari-hari manusia saling terhubung melalui dengan adanya perkembangan teknologi yang mempermudah mereka dalam berkomunikasi. Ditinjau dari sejarah masyarakat, penggunaan media komunikasi oleh manusia untuk mengatasi batas jarak antara yang satu dengan yang lainnya. Hal ini tidak mungkin dapat dicapai dengan hanya jarak interaksi yang normal yang biasa saling berhadapan. Maka dari itu dalam perkembangan teknologi perilaku manusia juga berkaitan dalam interaksi dengan menggunakan teknologi.

Menurut O'Breien dalam buku yang berjudul Pornomedia: Sosiologi Media, Komunikasi Sosial, Teknologi Informatika, Kebudayaan Seks di Media Massa (Bungin: 2009), perilaku manusia dan teknologi memiliki interaksi dalam lingkungan sosioteknologi. Ada lima komponen perilaku manusia dan teknologi dalam berinteraksi meliputi : struktur masyarakat, sistem dan teknologi informasi, masyarakat dan budaya, strategi komunikasi, proses sosial. Hal ini sangat berkaitan dengan perkembangan new media dan penggunaanya sebagai tools dalam kemunikasi massa. Selain itu, media bukan hanya penyampai pesan tapi telah menjadi "subjek" yang mempengaruhi sikap dan 
perilaku masyarakat itu sendiri (Gemiharto, Abdullah, Puspitasari, 2017:13)

Sebuah penelitian yang dilakukan oleh Wahyudin, Ronauli, Elita, Mirawati (2016:125) menunjukkan bahwa iklan atau kampanya baik melalui media sosial berpengaruh terhadap sikap dan gaya hidup masyarakat.

Menurut Gerbner (1967), komunikasi massa adalah proses produksi dan distribusi pesan secara luas dan berkelanjutan oleh institusi (organisasi) berlandasan teknologi dalam industri (Rakhmat, 2003:188). Dalam hal ini yang dimaksud ialah wujud baru dari media massa yang disebut sebagai new media. Salah satunya peran yang dimiliki oleh new media adalah promosi produk yang dilakukan melalui internet sebagai medianya.

Perkembangan media turut ambil bagian dalam penyebaran informasi khusunya dalam beriklan. Media online atau internet menjadi salah satu media yang mainstream yang pada saat ini dijadikan sebagai alat untuk beriklan dengan tujuan untuk mempromosikan suatu produk. Dengan adanya media online dapat
Iklan merupakan salah satu dari bauran promosi yang paling umum digunakan oleh sebuah perusahaan atau brand untuk memberikan informasi mengenai kelebihan produk kepada khalayak dan konsumennya. Dalam periklanan, media online dijadikan sebagai salah pilihan untuk beriklan dengan cepat dan murah. Hanya dengan mengakses internet sebuah perusahaan dapat mengiklankan produk yang mereka akan rilis dan jual di dalam pasar. Oleh karena itu, jumlah penggunaan internet juga menjadi pertimbangan oleh perusahaan untuk mengiklankan produknya.

Menurut Kementrian Komunikasi dan Informatika Republik Indonesia (KOMINFO) berdasarkan dari pemberitaan yang ada dari Kompas.com pada tahun 2015 yang ada pada web site kominfo, jumlah penggunaan internet di Indonesia akan mengalami peningkatan yang cukup pesat dan Indonesia mendapat peringkat 6 di dunia dalam peningkatan jumlah penggunaan internet. Hal ini dapat dilihat dari jumlah pengguna internet dari tahun ke tahun yang terus meningkat. mempermudah suatu perusahaan

untuk

mempromosikan

produknya secara luas dan mudah diakses oleh setiap orang baik melalui komputer bahkan lewat handphone mereka. Dengan menggunakan media

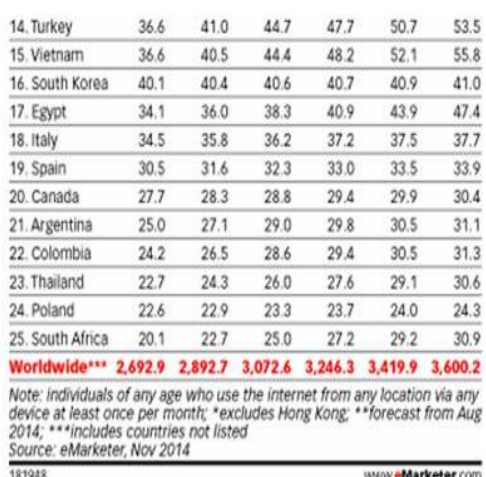

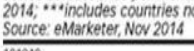

online perusahaan dapat beriklan dengan target audience yang luas.
Gambar 1. Pengguna internet dari tahun ke tahun 
Sumber :

(eMarketer dalam KOMINFO, 2014)

Dengan adanya peningkatan jumlah user atau pengguna internet, produsen akan mulai meminati penggunaan layanan internet sebagai media untuk beriklan produk mereka. Iklan yang menggunakan media internet disebut sebagai iklan online. Iklan online tersebut memiliki beragam format seperti banner, skyscraper, pop-up, pop-behind, minisite, superstitial, dan widgets (Moriarty, 2011:352).

Pada saat ini hampir semua website dapat ditemukan iklan online, mulai dari blogspot, website berita, hingga situs jejaring sosial seperti Facebook, Twitter, Path, Instagram, YouTube, dan sebagainya yang menjadi media yang banyak digunakan dalam beriklan dengan tujuan untuk mempromosikan produk mereka. Namun kini media yang paling sering digunakan dalam beriklan lewat media online adalah situs YouTube.

YouTube merupakan sebuah situs web video sharing (berbagi video) populer dimana para user (pengguna) dapat memuat, menonton, dan berbagi video secara gratis. Umumnya video-video yang ada di YouTube adalah video klip, film, TV, serta video buatan yang dibuat oleh para penggunanya sendiri. Media sosial YouTube sangat digemari oleh masyarakat mulai dari anakanak hingga orang dewasa. Baik untuk sekedar melihat video ataupun mengunggah video kedalam YouTube. Bukan hanya itu saja YouTube sendiri juga memiliki manfaat, diantaranya untuk mencari film, melihat musik, video terbaru, melihat tayangan ulang berita, atau sebagai pusat informasi dan lain sebagainya.

YouTube juga merupakan situs video online yang paling sering, dikunjungi oleh pengguna internet di seluruh dunia bahkan hingga di Indonesia baik melalui komputer bahkan smartphone mereka. Ini yang membuat YouTube menempati peringkat kedua pada "Top Sites" setelah google pada Alexa Rank dalam kategori global. Sedangkan pada ranking "Top Site" di Indonesia berdasarkan pada Alexa Rank, YouTube berada pada posisi ke-tiga setelah google.co.id dan google.com (Alexa Top site, 2016). Hal ini menjadi salah satu alasan oleh para perusahaan ataupun produsen tertarik untuk mengiklankan produk yang mereka tawarkan kepada orang-orang.

Berdasarkan data pada web site similar (https://www.similarweb.com) YouTube berada pada peringkat 3 di dunia. Melihat dari perbandingan jenis situs yang sama seperti Vimeo.com dan Dailymotion.com, YouTube berada pada peringkat atas berdasarkan jumlah akses pada web site. Jumlah total pengunjung web site YouTube sebesar 20,5 milyar user, Vimeo sebanyak 195,7 juta user, dan Dailymotion dengan 257,7 juta user. Data tersebut berdasarkan pada bulan September 2016 hingga Februari 2017. Sedangkan untuk 
di Indonesia YouTube berada pada peringkat

3 dibawah dari google.com dan juga Facebook berdasarkan data terbaru pada tanggal 1 Maret 2017 pada web site Similar. Dilihat dari kategori situs yang sama YouTube berada dalam posisi pertama diikuti dari Uzone.id, wikia.com, dan juga video.com.

(Sumber: https://www.similarweb.com diakses pada tanggal 6 April 2017)

Iklan-iklan yang ada di YouTube termasuk online advertising atau biasa disebut iklan online. Yang sifatnya hanya bisa diakses pada saat surfing atau menjelajah di dunia digital (internet). Jumlah iklan yang telah di upload di YouTube hingga pada saat ini sudah sangat banyak. Maka dari itu iklan yang ditampilkan di YouTube bersifat random atau teracak. Jadi pada setiap mengakses video yang ada di YouTube pasti akan muncul iklan pop-up. Iklan yang muncul bisa berupa banner, video, gambar, iklan terawang, dan sebagainya.

Salah satu contoh iklan gambar yang muncul saat pemutaran video klip berlangsung. Iklan gambar tersebut termasuk dalam iklan link atau link adv. Iklan ini tergolong ke dalam salah satu iklan online yang menampilkan sebuah gambar yang apabila gambar tersebut di klik akan menuju sebuah link website. Tapi di YouTube iklan gambar seperti pada gambar di bawah ini tidak selalu muncul dan dapat ditutup apabila muncul.
Sedangkan iklan yang paling sering muncul di YouTube adalah iklan pop-up yang berupa video atau pun bumper. Iklan pop-up merupakan iklan yang kemunculannya mendadak di layar monitor di depan halaman pada saat membuka web site (Moriarty 2011: 352). Hal ini sama halnya dengan yang ada di YouTube yaitu ketika meng-klik video yang akan diputar iklan tersebut akan muncul dan memutar sendiri atau yang dikenal dengan auto play. Iklan pop-up ini ada bisa di skip (dilewati) dan ada yang tidak bisa. Tergantung dari jenis iklan yang ditayangkan oleh YouTube. Kebanyakan iklan-iklan yang tayang pada saat pemutaran video itu beragam mulai dari iklan produk kecantikan, iklan sampo, iklan bank, dan berbagai macam.

Durasi iklan yang ada iklan di YouTube khususnya iklan pop-up bermacam-macam. Ada yang 5 detik, 10 detik, bahkan hingga ada yang 1 menit bahkan lebih tergantung dari jenis iklannya. Hal ini memberikan banyak respon dari para khalayak yang menonton iklan tersebut. Ada yang menganggap hal tersebut biasa atau bagus bahkan menarik dan melanjutkan untuk menonton iklan tersebut. Hal ini mungkin yang membuat para produsen tertarik untuk beriklan di YouTube. Karena beranggapan bahwa dengan beriklan di YouTube memungkinkan produk mereka lebih cepat dikenal oleh masyarakat dan tertarik untuk membelinya. Namun ada juga khalayak yang merasa terganggu dengan iklan-iklan tersebut sehingga mereka meng-klik skip-ad 
untuk melewati iklan tersebut. Hal ini sarana jual-beli dari konsumen ke konsumen. tergantung dari sikap khalayak terhadap suatu iklan.

Siapa pun dapat membuka toko online di Bukalapak dan melayani pembeli dari seluruh

Sikap juga disebut sebagai konsep yang khusus dan sangat dibutuhkan dalam psikologis sosial kontemporer. Sikap juga merupakan salah satu konsep yang paling penting yang digunakan marketer untuk memahami konsumen (Setiadi, 2008: 214).

Indonesia untuk transaksi satuan maupun banyak (Sumber : www.Bukalapak.com diakses pada tanggal 17 September 2016 pukul 10.30 wib). Model online marketplace ini menyediakan rekening bersama untuk pembeli dan penjual. Berdasarkan dari survei Top

Salah satu faktor yang mempengaruhi perusahaan dalam beriklan adalah faktor sikap. Para pengiklan telah lama untuk mengukur sejauh mana konsumen mengevaluasi iklan. Sikap konsumen terhadap iklan dapat mempengaruhi sikap mereka terhadap produk atau brand yang diiklankan. Iklan yang di senangi konsumen atau khalayak telah terlihat menciptakan sikap merek yang positif dan keinginan untuk membeli yang lebih dari pada iklan yang tidak mereka sukai. Mekanisme yang dapat menjelaskan dampak menyukai terhadap suatu merek tidak diketahui. Mungkin saja dengan suka terhadap suatu iklan dapat mempengaruhi perhatian dan pemahaman khalayak terhadap suatu iklan (Peter dan Olson, 2000: 195).

Salah satu perusahaaan yang sering beriklan melalui situs YouTube adalah Bukalapak. Hal ini dapat dilihat dari jumlah video iklan yang di unggah ke dalam situs YouTube sebesar 222 video iklan pada bulan Februari 2017. Bukalapak adalah salah satu online marketplace terkemuka di Indonesia. Seperti halnya situs layanan jual-beli menyediakan brand Indonesia Bukalapak berada pada peringkat 4 dibawah dari Olx, Lazada, Tokopedia dan untuk peringkat 5 dan 6 yaitu elevenia dan kaskus pada tahun 2016. Berdasarkan dari klasifikasi model bisnisnya yang hanya masuk pada online marketplace yaitu Bukalapak, Tokopedia, dan Elevenia sedangkan Olx dan Kaskus masuk dalam model bisnis classifieds atau listing online yang ada pada Top Brand Indonesia. Pada total total video yang di upload Tokopedia sebanyak 136 dan Elevania 59 video yang di unggah ke YouTube pada bulan Februari 2017. Berdasarkan dari klasifikasi model bisnis dan data statistik diatas hal ini yang membuat penulis memilih Bukalapak yang hanya mengunggah 222 video di YouTube sebagai objek penelitian. Bukan hanya itu saja pada waktu bulan Agustus - Oktober Bukalapak sedang menggelar festival iklan dengan tema pahlawan sehingga pada bulan tersebut iklan pop-up bukalapak yang tayang pada YouTube ialah iklan-iklan versi pahlawan. Berdasarkan dari pemaparan diatas, hal ini yang membuat penulis memilih Bukalapak yang hanya meng- 
upload 222 video di YouTube sebagai objek penelitian. Iklan-iklan mengenai Bukalapak di YouTube sangat sering tayang atau ditonton oleh khalayak. Hal ini bisa dilihat dari jumlah penayangan atau jumlah video iklan mengenai Bukalapak yang ditonton di YouTube. Salah satu iklan yang sering tayang ialah "Ayo Ikutan Festival Iklan Bukalapak Berhadiah 525 Juta Rupiah" yang jumlah penayangannya lebih dari 4 juta kali.

Iklan tersebut mengajak para khalayak atau YouTubers untuk membuat iklan tentang bukalapak dengan tema pahlawan. Iklan tersebut merupakan sebuah Festival Iklan yang dibuat oleh Bukalapak hal ini yang dimaksud adalah sebuah kompetisi dengan tujuan untuk menginspirasi sekaligus mengembangkan kreativitas dan potensi dengan membuat video iklan Bukalapak dengan tema Pahlawan (Sumber: Bukalapak, 2016). Berdasarkan dari iklan tersebut beragam tanggapan yang ada dari khalayak. Tanggapan-tanggapan tersebut banyak yang berupa tentang video yang ditampilkan. Ada juga yang berupa cara pendaftaran kompetisi tersebut.

Jumlah video viewers dan subscribe mengenai Bukalapak bisa dilihat dari tampilan data yang ada di bawah.jumlah video yang telah ditonton sebanyak 50 juta viewers dan untuk jumlah subscribe untuk Bukalapak yang ada di YouTube ada sekitar 20 ribu orang. Data statistik tersebut dilihat pada hari Sabtu pada tanggal 17 september
2016. Data statistik berikut ini menampilkan jumlah subscribe dan video viewers dari hari ke hari. Data tersebut diambil dari web site socialblade. Socialblade merupakan web site statistik yang memperbolehkan kita untuk menulusuri data statistik dan mengukur pertumbuhan dari berbagai macam platform media social termasuk YouTube, facebook, twitter, dan sebagainya (Sumber: Socialblade, 2016). Dari data statistik yang dibawah ini juga dapat dilihat juga jumlah pendapatan yang didapatkan dari unggahan video di YouTube yang dilihat setiap harinya. Data yang di Socialblade merupakan data yang up to date atau data yang diperbaharui setiap waktu.

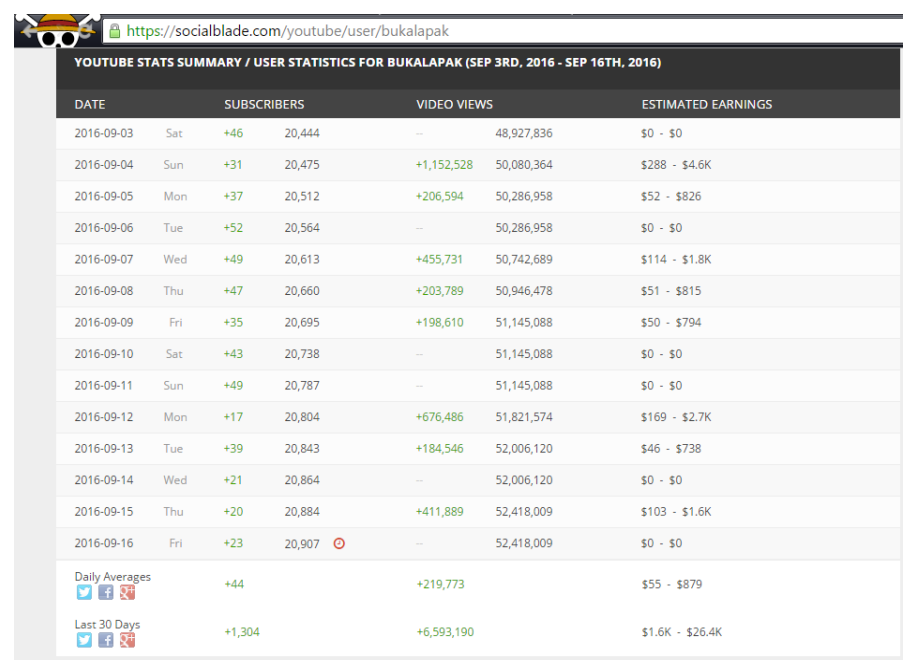

Gambar 2

Tampilan data statistik Bukalapak di YouTube dari Social blade Sumber: (Statistik Bukalapak dalam ocialblade diakses pada tanggal 17 September 2016 pukul 10.43 wib)

Dari paparan diatas, terdapat suatu fenomena yang menarik dimana banyak iklan yang berada di web site khususnya YouTube 
yang jumlahnya semakin meningkat pada tahun 2016. Baik iklan pop-up, gambar, banner, video, dan lain sebagainya yang memberikan pengaruh terhadap khalayaknya baik yang sifatnya positif ataupun negatif. Iklan dari Bukalapak dengan judul "Ayo Ikutan Festival Iklan Bukalapak” merupakan salah satu dari iklan-iklan yang banyak memiliki tanggapan-tanggapan baik dari subscribe-nya ataupun dari yang menontonnya. Pada sekarang ini iklan pop-up Bukalapak yang jenisnya video ditayangkan pada YouTube merupakan hasil dari festival iklan tersebut dengan iklan yang bertemakan pahlawan.

Iklan tersebut merupakan iklan pop-up yang ada di YouTube berdasarkan dari jumlah rata-rata pemutaran iklan pop-up tersebut yang kira-kira sekitar 50 ribu kali ditonton oleh khalayak selama kurang lebih hampir sebulan yaitu 26 hari yang bisa dilihat pada data statistic di atas. Berdasarkan dari statistik video yang terhitung sampai 10 Oktober 2016 yang bisa dilihat langsung pada YouTube diakses pada tanggal 13 Oktober 2016 iklan pop-up tersebut di upload tanggal 15 September 2016 dalam waktu hampir sebulan telah tayang di YouTube sebanyak 1.888.843 penayangan yang terhitung sampai tanggal 10 Oktober 2016. Hal ini yang membuat peneliti tertarik untuk mengetahui apakah adsa pengaruh iklan Pop-up Bukalapak versi pahlawan yang ada di YouTube terhadap sikap khalayak.
Berdasarkan dari uraian latar belakang diatas, maka peneliti mengajukan rumusan masalah, yakni sebagai berikut : Apakah terdapat pengaruh iklan Pop-up Bukalapak Versi Pahlawan pada YouTube terhadap sikap khalayak ?

\section{Komunikasi Pemasaran}

Komunikasi pemasaran adalah media yang digunakan oleh perusahaan-perusahaan dalam upaya untuk memberikan informasi, membujuk, dan juga sebagai pengingat untuk konsumen baik secara langsung atau tidak langsung mengenai produk, jasa atau brand yang perusahaan jual. Komunikasi pemasaran juga disebut sebagai bauran pemasaran. Disebut sebagai bauran pemasaran karena biasanya para marketer sering menggunakan berbagai jenis bauran promosi secara serentak dan teritegrasi dalam suatu rencana atau rancangan promosi produk. Bagian-bagian dari bauran promosi adalah iklan (advertising), promosi penjualan (sales promotion), penjualan tatap muka (personal selling), hubungan masyarakat dan publisitas (public relation and publicity), serta pemasaran langsung. (Setiadi, 2003:251)

\section{Iklan}

Iklan (advertising) adalah penyajian informasi nonpersonal tentang suatu produk, merek, perusahaan, atau toko yang dilakukan dengan bayaran tertentu. Pada iklan biasanya ditampakkan organisasi yang mensponsorinya. Iklan ditujukan untuk mempengaruhi afeksi dan kognisi konsumen- 
evaluasi, perasaan, pengetahuan, makna, kepercayaan, sikap, dan citra yang berkaitan dengan produk atau merek. Dalam prakteknya, iklan telah dianggap sebagai manajemen citra (image management). Manajemen citra ialah menciptakan dan memelihara citra (image) dan juga makna dalam benak konsumen. Walaupun pertamatama iklan akan mempengaruhi afeksi dan kognisi tetapi tujuannya yang paling akhir adalah bagaimana mempengaruhi perilaku pembelian konsumen. (Peter dan Olson, 2000: 181)

Dalam iklan audio-visual seperti televisi, internet (seperti YouTube), dan juga media luar ruang (seperti Videotron). Upaya menarik perhatian merupakan pekerjaan yang sangat menantang karena faktor persaingan dengan iklan lainnya. Sebagaimana iklan media cetak yang memiliki beberapa komponen, maka iklan yang ada pada televisi ataupun iklan pop-up YouTube yang berupa video terdiri atas komponen video (visual) dan audio. Sebagaimana yang dijelaskan oleh Morissan dalam buku Periklanan komunikasi pemasaran terpadu (2010: 365).

1. Video

Elemen video iklan televisi adalah sesuatu yang terlihat di layar televisi. Elemen visual adalah elemen yang mendominasi iklan televisi sehingga elemen ini harus mampumenarik perhatian sekaligus dapat menyampaikan ide, pesan, dan/atau citra yang hendak ditampilkan. Pada iklan televisi, sejumlah elemen visual harus dikoordinasikan atau diatur sedemikian rupa agar dapat menghasilkan iklan yang berhasil. Pembuat iklan harus memutuskan berbagai hal seperti: urutan aksi, demonstrasi, lokasi, pencahayaan, grafis, warna, hingga kepada siapa bintang iklannya.

2. Audio

Komponen audio dari suatu iklan televisi terdiri dari suara, music, dan sound effects. Suara dapat didengar melalui suatu presentasi langsung oleh seorang penyaji (presenter) atau dalam bentuk percakapan diantara sejumlah orang yang muncul pada iklan bersangkutan. Perusahaan iklan seringkali menggunakan suara artis atau pengisi suara (dubber) lainnya yang memiliki karakter suara yang bagus dan menarik. Musik dapat digunakan sebagai alat untuk menarik perhatian, menyampaikan pesan penjualan dan membantu membangun citra suatu produk. Music dapat menciptakan suasana hati yang positif yang dapat membuat konsumen lebih bisa menerima (receptive) terhadap produk bersangkutan. Elemen music penting lainnya adalah jinggel (jingle), yaitu lagu yang menarik perhatian yang biasanya memuat pesan iklan sederhana mengenai suatu barang atau jasa atau dengan kata lain jinggel adalah lagu yang diciptakan khusus untuk iklan suatu produk.

\section{Iklan Internet}


Dengan adanya perkembangan teknologi pada zaman ini, ribuan pemasar telah berpaling ke internet sebagai sebuah media prospektif untuk mempromosikan merekmerek mereka dan melakukan transaksi penjualan. Para marketer atau pemasar telah berbondong-bondong untuk pamer diri pada situs web yang dikenal sebagai homepage. Kebanyakan dari mereka menawarkan iklaniklan produk atau jasa perusahaan mereka (Lee \& Carla Johnson, 2011:386).

Format yang ada pada iklan internet, Sandra Motiarty, Nancy Mitche, dan Willian Wells (2007:313) yang berjudul Advertising mengklasifikasikan jenis-jenis format iklan internet, yaitu Iklan Banner, Skyscrapers, Pop-up dan Pop-behind, Minisite, Superstitial. Iklan Pop-up Pop-up, yakni kemunculan mendadak dilayar monitor di depan halaman pada saat membuka web site.

Berdasarkan format iklan pop-up yang telah dijelasakan di atas maka kebanyakan iklan internet di web site YouTube merupakan iklan internet atau iklan online dengan format pop-up. Format iklan pop-up di YouTube ini sering tiba-tiba muncul ketika akan memutar video yang ingin kita tonton. Bentuk iklan yang digunakan dalam iklan ini adalah berbentuk video atau audiovisual dimana mengandung unsur suara dan juga gambar gerak. Ketika pemutaran iklan pop-up tersebut sedang berlangsung, akan muncul ikon tulisan nama iklan tersebut dan nama web site yang beriklan di YouTube. Apabila ikon tersebut di klik maka otomatik kita akan masuk ke web site pengiklan tersebut. Jenis-jenis format iklan pop-up yang di YouTube antara lain iklan terawang, iklan video yang dapat diabaikan setelah 5 detik, Iklan video yang tidak dapat diabaikan dan iklan video panjang yang tidak dapat diabaikan, dan iklan bumper. (sumber: YouTube, 2016)

\section{Sikap}

Sikap disebut juga sebagai konsep yang paling khusus dan sangat dibutuhkan dalam psikologis social kontemporer. Sikap juga merupakan salah satu konsep yang paling penting yang digunakan oleh marketer untuk memahami karakteristik dan perilaku dari konsumen (Setiadi 2008: 214).

Kepercayaan terhadap suatu merek, evaluasi merek dan maksud untuk membeli suatu produk merupakan tiga komponen dari sikap. Kepercayaan terhadap merek adalah komponen kognitif dari sikap, evaluasi merek adalah komponen afektif atau perasaan, dan

Komponen Kognitif

Kepercayaan terhadap merek

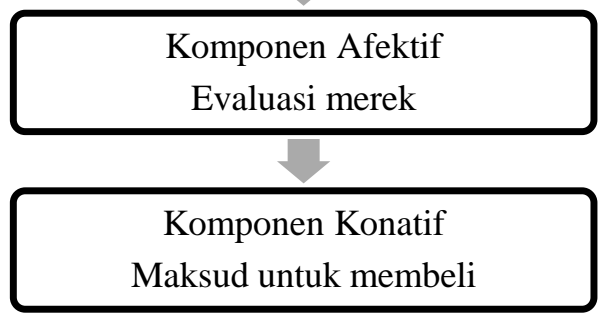


maksud untuk membeli adalah komponen konatif atau tindakan. Hubungan antara ketiga komponen ini dijelaskan pada gambar dibawah ini.

\section{Gambar 3}

Hubungan Antara 3 Komponen Sikap Sumber : Setiadi, 2008:217

Menurut tiga komponen sikap, sikap terdiri dari tiga komponen utama yang dimulai dari komponen kognitif, komponen afektif, dan komponen konatif (Schiffman dan Kanuk, 2008:225-227), yakni:

\section{1) Komponen Kognitif}

Komponen pertama dari tiga komponen sikap terdiri dari berbagai kognisi (kognitif) seseorang, yaitu pengetahuan dan persepsi yang diperoleh berdasarkan kombinasi pengalaman langsung dengan obyek sikap dan informasi yang berkaitan dari berbagai sumber. Pengetahuan dan persepsi yang ditimbulkan biasanya mengambil bentuk kepercayaan yaitu, kepercayaan konsumen bahwa obyek sikap mempunyai berbagai sikap dan perilaku tertentu akan menimbulkan hasil-hasil tertentu. Dengan kata lain, komponen kognitif dari sikap konsumen dipengaruhi oleh pengetahuan, persepsi, pengalaman, pengamatan serta pemahaman yang diperolehnya melalui objek sikap yang dikomunikasikan yang akan menimbulkan kepercayaan.

2) Komponen Afektif
Emosi atau perasaan konsumen mengenai merek atau brand tertentu merupakan komponen afektif dari sikap tertentu. Emosi dan perasaan sering dianggap oleh para peneliti konsumen sangat evaluatif sifatnya; yaitu, mencakup penilaian seseorang secara langsung dan menyeluruh terhadap objek sikap yang "menyenangkan" atau "tidak menyenangkan". Pengalaman yang mengharukan juga dimanifestasikan sebagai keadaan yang diliputi emosi (seperti kebahagiaan, kesedihan, rasa malu, rasa muak, kemarahan, kesukaran, kesalahan, atau keheranan). Riset menunjukkan bahwa keadaan emosional ini dapat meningkatkan atau memperkuat pengalaman positif maupun negatif dan ingatan tentang pengalaman tersebut dapat mempengaruhi apa yang timbul dipikiran dan bagaimana individu bertindak. Pada intinya komponen afektif ini menunjukkan arah sikap yang dimiliki oleh konsumen yaitu, arah positif dan arah negative.

\section{3) Komponen Konatif}

Konatif merupakan komponen terakhir dari komponen sikap yang berhubungan dengan kemungkinan atau kecenderungan bahwa individu akan melakukan tindakan khusus atau berperilaku dengan cara tertentu terhadap objek tertentu. Menurut beberapa penafsiran, komponen konatif mungkin mencakup perilaku sesungguhnya itu sendiri. Dalam riset pemasaran dan konsumen, komponen konatif sering dianggap sebagai 
pernyataan untuk maksud konsumen untuk membeli. Skala maksud pembeli digunakan untuk menilai kemungkinan konsumen untuk membeli suatu produk atau berperilaku menurut cara tertentu.

\section{METODE PENELITIAN}

Jenis penelitian ini menggunakan mentode kuantitatif. Metode kuantitatif adalah metode yang tersusun secara sistematis dandikembangkan dengan model matematis. Metode penelitian ini bisa digunakan untuk meneliti fenomena komunikasi dan fenomena - fenomena sosial lainnya, oleh karena itu peneliti memutuskan untuk menggunakan pendekatan kuantitatif. Metode kuantitatif menuntut peneliti untuk melakukan pengamatan yang dapay diubah kedalam bentuk angka dan melakukan analisis angkaangka tersebut (Rubin, Palmgreen, \& Sypher dalam West, 2009: 77). Sekaran (2007: 158) berpendapat bahwa penelitian desktiptif (descriptive research) dilakukan untuk mengetahui dan menjadi mampu untuk menjelaskan karakteristik variabel yang diteliti dalam suatu situasi. Studi deskriptif digunakan pada penelitian ini untuk menjawab rumusan permasalahan awal, yaitu penjelasan mengenai respon sikap khalayak terhadap komponen audiovisual iklan pop-up Bukalapak versi pahlawan pada YouTube.

Dalam penelitian ini terdapat variabel dependen (Sikap Khalayak) dan variabel independen (iklan pop-up). Subvariabel dependen ialah komponen kognitif, afektif, dan konatif sedangkan subvariabel independennya adalah komponen audio dan video. Dalam memperoleh data peneliti menggunakan metode kuisioner. Menurut Kriyantono (2009:59), metode survei adalah metode dengan menggunakan kuisioner sebagai instrumen pengumpulan datanya. Tujuannya untuk memperoleh informasi tentang sejumlah responden yang dianggap mewakili populasi tertentu. Dalam memperoleh data kuisioner, peneliti menggunakan insidental sampel yaitu teknik penentuan sampel berdasarkan kebetulan, yaitu siapa saja yang secara kebetulan atau insidental bertemu dengan peneliti dapat digunakan sebagai sampel, bila dipandang orang yang kebetulan ditemui itu sesuai sebagai sumber data (Sugiyono, 2009: 122). Sampel dalam penelitian ini adalah mahasiswa Universitas Telkom dengan diketahui jumlah data populasinya yaitu 27.266 mahasiswa yang tercatat pada tahun ajaran 2015-2016. Maka dari itu peneliti menggunakan rumus Slovin (Sujarweni, 2015: 81-82) yang jumlah populasinya sudah diketahui sehingga dapat diketahui jumlah sampel yang digunakan ialah 99,63 untuk mengatasi ketidakvalidan data maka digenapkan menjadi 100 sampel.

\section{HASIL DAN PEMBAHASAN}


Tanggapan responden terhadap iklan popup Bukalapak versi pahlawan pada YouTube.

Pada penelitian ini ada 2 komponen iklan Pop-up Bukalapak versi pahlawan yaitu komponen Audio dan komponen Visual. Dari hasil penelitian dapat diatrik simpulann item pernyataan yang memberikan nilai paling tinggi adalah item no. 4 yaitu video iklan popup bukalapak versi pahlawan menarik dengan total skor 295 dari keseluruhan sampel dengan nilai rata-rata $73,75 \%$. Adapun item pernyataan yang memiliki nilai paling rendah ialah item no. 8, Iklan pop-up bukalapak versi pahlawan tidak menampilkan kesan humor dengan total skor 256 dari keseluruhan sampel dengan nilai rata-rata $64 \%$. Sedangkan untuk keseluran total skor dan rata-rata persentase total dari iklan pop-up Bukalapak versi pahlawan yaitu 3988 dan $71,2 \%$.

Iklan pop-up Bukalapak versi pahlawan pada YouTube (Variabel X) telah memenuhi tujuan dari iklan. Sesuai dengan yang dijelaskan oleh Setiadi (2008: 253) yaitu adapun tiga tujuan utama dari iklan yaitu menginformasikan (informative), membujuk (persuade), dan mengingatkan (reminding). Hal ini bisa dilihat dari rata-rata total skor dari iklan pop-up tersebut adalah 71,21\% dapat dilihat pada tabel 4.1 masuk dalam kategori baik. Dapat disimpulkan iklan pop-up Bukalapak versi pahlawan telah memenuhi tiga tujuan utama dalam beriklan.

\section{Sikap khalayak yang menonton iklan pop- up Bukalapak versi pahlawan pada YouTube. \\ Pada penelitian sikap khalayak yang} diteliti adalah sikap khalayak terhadap iklan. dalam penelitian ini untuk mengukur sikap khalayak terhadap iklan pop-up bukalapak versi pahlawan pada YouTube. Komponen sikap yang diukur terdiri dari 3 komponen yaitu: Kognitif, Afektif, dan Konatif. item pernyataan yang memberikan nilai paling tinggi adalah item no. 15 yaitu Iklan pop-up bukalapakak versi pahlawan di YouTube sangat menarik untuk di lihat dengan total skor 288 dari keseluruhan sampel dengan nilai rata-rata $72 \%$. Adapun item pernyataan yang memiliki nilai terendah ialah item no. 34, Saat muncul ikon skip-ad pada detik ke-5, saya tetap menonton iklan pop-up hingga selesai dengan total skor 246 dari keseluruhan sampel dengan nilai rata-rata $61,5 \%$. Sedangkan untuk keseluran total skor dan rata-rata persentase total dari sikap khalayak yaitu 5404 dan $67,55 \%$.

Sikap khalayak (Y) merupakan salah satu faktor yang mempengaruhi suatu brand dalam beriklan. Sikap khalayak terhadap suatu iklan data mempengaruhi sikap terhadap brand yang diiklankan (Peter dan Olson, 200:195). Simpulan yang dapat ditarik dari sikap khalayak terhadap iklan pop-up Bukalapak masih tergolong dalam kategori baik karena berdasarkan dari rata-rata dari total skor yaitu 67,55\% dilihat dari komponen kognitif, afektif dan konatifnya. 
Berdasarkan dari data penelitian yang didapat, ditemukan adanya pengaruh Iklan pop-up Bukalapak versi pahlawan terhadap sikap khalayak. Pengaruh yang terjadi ditinjukkan dengan hasil nilai pengujian hipotesis pada penelitian ini. Nilai Sig penelitian adalah $0,00<0,10(10 \%)$ dan nilai t hitung sebesar 11,523 > nilai t tabel 1,292. Iklan pop-up tersebut berpengaruh positif terhadap sikap khalayak dapat dilihat dari hasil perhitungan regresinya dengan rumus berikut:

\section{$\hat{\mathbf{Y}}=16,340+1,199 \mathrm{X}$}

Untuk mengetahui seberapa besar pengaruh variabel iklan pop-up bukalapak versi pahlawan pada YouTube terhadap sikap khalayak dapat dilihat dari koefisien korelasi dan perhitungan koefisien determinasi. Nilai koefisien korelasi berdasarkan dari hasil penelitian ialah 0,759 masuk kedalam kategori kuat karena berada diantara nilai 0,60-0,799 (Sugiyono, 2011: 231). Hal ini menunjukkan antara Iklan Pop-up Bukalapak versi pahlawan pada YouTube (variabel X) yang terdiri dari komponen audio dan visual mempunyai pengaruh tingkat kategori kuat terhadap sikap khalayak (variabel Y) dalam interpretasi koefisien korelasi. Sedangkan dilihat dari nilai koefisien determinasi sebesar 0,575 atau $57,5 \%$ perubahan yang terjadi pada sikap khalayak dipengaruhi oleh iklan pop-up bukalapak pada YouTube. Sedangkan sisanya sebesar $42,5 \%$ di pengaruhi oleh faktor lain yang tidak diamati dalam penelitian ini.

\section{SIMPULAN}

Berdasarkan hasil analisa dan pengolahan data pada penelitian tentang "Pengaruh Iklan Pop-up Bukapalak Versi Pahlawan Pada YouTube Terhadap Sikap Khalayak", maka dapat disimpulkan bahwa terdapat pengaruh iklan pop-up bukalapak versi pahlawan pada YouTube terhadap sikap khalayak. Hal ini membuktikan bahwa hipotesis $\mathrm{H}_{1}$ diterima. Hasil penelitian ini berdasarkan tanggapan responden mengenai iklan pop-up Bukalapak versi pahlawan pada YouTube berkategori baik, iklan pop-up Bukalapak versi pahlawan telah memenuhi tujuan utama dari sebuah iklan. Jalan cerita iklan yang dikemas dengan menarik dan memberikan informasi mengenai Bukalapak dan juga festival iklan yang digelarnya. Iklan pop-up tersebut telah menyampaikan pesannya dengan cara persuasif dan juga mudah diingat oleh khalayak. Hasil dari penelitian ini juga menemukan sikap khalayak pada saat menonton iklan pop-up Bukalapak versi pahlawan pada YouTube berada dalam kategori yang baik dilihat dari komponen sikap yaitu kognitif, afektif, dan juga konatif. Iklan pop-up Bukalapak pada YouTube versi pahlawan berpengaruh positif terhadap sikap khalayak. Pengaruh iklan popup Bukalapak versi pahlawan pada YouTube terhadap sikap khalayak sebesar 57,5\%, 
sedangkan sisanya sebesar $42,5 \%$ sikap

khalayak dipengaruhi oleh faktor luar.

\section{DAFTAR PUSTAKA}

Alexa Top Site. (2016). Top sites In Indonesia. Diakses dari http://www.alexa.com/topsites/countrie s/ID pada tanggal 3 September 2016 pukul 10.15

Bukalapak. (2016). Tentang Bukalapak. Diakses dari https://www.bukalapak.com/about pada tanggal 17 September 2016 pukul 10.30 wib

Bungin, Burhan. 2009: Pornomedia: Sosiologi Media, Komunikasi Sosial, Teknologi Informatika, Kebudayaan Seks di Media Massa. Bandung: Prenada Media Group.

EMarketer dalam Kominfo, Wicak. (2014). Pengguna Internet Indonesia Nomor Enam Dunia. Diakses dari https://kominfo.go.id/content/detail/42 86/pengguna-internet-indonesianomor-enam-dunia/0/sorotan_media pada tanggal 27 Agustus 2016 pukul $11.50 \mathrm{wib}$

Gemiharto, I., Abdullah A., Puspitasari, L., 2017, Kajian Kritis Tayangan

Televisi Favorit Kelas Menengah Perkotaan, Jurnal ProTVF Volume 1 Nomor 1 diakses melalui http://jurnal.unpad.ac.id/protvf/article /view/13329

Kriyantono, Rachmat. 2009: Teknik Praktis Riset Komunikasi. Jakarta Kencana Prenada Media Group.

Lee Monle \& Carla Johnson, 2011: Prinsipprinsip Pokok Periklanan Dalam Perspektif Global. Jakarta: Kencana Prenada Media Group

Morissan. 2010: Periklanan: Komunikasi Pemasaran Terpadu. Jakarta: Kencana.

Peter, J. Paul dan Jerry C Olson. 2000: Consumer behavior: Perilaku Konsumen Dan Strategi Pemasaran
Jilid 1. Edisi Keempat. Jakarta: Erlangga.

Rakhmat, Jalaludin, 2003: Psikologi Komunikasi, Bandung: PT. Remaja Rosdakarya.

Ronauli, M., Wahyudin, U., Elita, F.U., Mirawati, I., 2016, HUBUNGAN ANTARA PESAN KAMPANYE 9 AKSI RAMAH LINGKUNGAN DI AKUN TWITTER EARTH HOUR BANDUNG DENGAN SIKAP FOLLOWERS AKTIF TERHADAP GAYA HIDUP RAMAH LINGKUNGAN, diakses dari http://jurnal.unpad.ac.id/manajemenkomunikasi/article/view/11017/4924

Sandra Moriarty, William Wells, John Burnett, \& May Lwin. 2007: Advertising. Singapura: Pearson Education South Asia.

Sandra Moriarty, dkk. 2011: Advertising. Jakarta: Kencana.

Sekaran, Uma. 2007: Research Methods for business Edisi 4 Buku 1. Jakarta: Salemba Empat.

Setiadi, Nugroho 2003: Perilaku Konsumen. Jakarta: Kencana Prenada Media Group.

Setiadi, Nugroho 2008: Perilaku Konsumen. Jakarta: Kencana Prenada Media Group.

Similarweb. (2017). Digital Marketing Intelligence and Website Trafic. Diakses dari https://www.similarweb.com/ pada tanggal 6 April 2017 Pukul 12.40 Wib

Socialblade. (2016). Youtube Statistic Channel. diakses dari https://socialblade.com pada tanggal 17 September 2016 pukul 11.00 wib

Statistik YouTube. (2016). YouTube Statistic. Diakses dari https://www.YouTube.com/yt/press/id/s tatistics.html pada tanggal 10 September 2016 pukul 10.30

Sugiyono. 2009: Metode Penelitian Bisnis. Bandung: Alfabeta

Sugiyono. 2011: Statistka Untuk Penelitian. Bandung: Alfabeta 
Sujarweni, V. Wiratna. 2015: Metode

Penelitian Bisnis dan Ekonomi.

Yogyakarta: Pustaka Baru Press

Yasundari. (2016). HUBUNGAN

PENGGUNAAN INSTAGRAM

DENGAN MOTIVASI WIRAUSAHA

PEBISNIS DARING (ONLINE)

DALAM MENINGKATKAN

PRODUKTIVITAS. Diakses dari

http://journal.unpad.ac.id/jkk/article/vi

ewFile/7737/pdf tanggal 29 Maret 2017.

YouTube. (2016). Format Iklan Pada

YouTube. Diakses dari

https://support.google.com/youtube/a

nswer/2467968?hl=id pada tanggal 2

September 2016 pukul 14.44 